\title{
SURVEI MODEL PEMBELAJARAN DARING KOMBINASI WHATSAPP PADA MATERI LARI ESTAFET KELAS VIII SMPN 1 KESAMBEN
}

\author{
Kahan Tony Hendrawan ${ }^{1)}$, Ridan Andi Puspito ${ }^{2)}$ \\ ${ }^{1}$ Pendidikan Jasmani, STKIP PGRI JOMBANG \\ email: kahan.stkipjb@gmail.com \\ ${ }^{2}$ Pendidikan Jasmani, STKIP PGRI JOMBANG \\ email: ridan23amell@gmail.com
}

\section{Artikel Info}

Koresponden penulis:

Nama penulis pertama

Email: kahan.stkipjb@gmail.com

Diterima 3 November 2021

$\square$ Direview 18 Januari 2022

Disetujui 29 Januari 2022

Dipublikasi 31 Januari 2022

\begin{abstract}
Abstrak
Tujuan dari penelitian ini adalah untuk mengetahui apakah model pembelajaran daring kombinasi whatsapp mempunyai pengaruh terhadap hasil pembelajaran lari estafet siswa siswi SMPN 1 Kesamben kelas tujuh (VIII) dimasa pandemi covid 19. Jenis penelitian yang digunakan dalam penelitian ini adalah deskriptif kuantitatif. Metode penelitian deskriptif adalah penelitian yang dilakukan untuk menggambarkan gejala, fenomena atau peristiwa tertentu (Sugiyono, 2007:11). Teknik analisis dalam penelitian ini menggunakan teknik anlisis deskriptif kuantitatif dengan hasil skor persentase. Hasil penelitian menunjukkan bahwa indikator sikap memperoleh 72,2\%, indikator teknik lari 61\%, indikator pengetahuan 74,3\%. Dapat disimpulkan bahwa pengetahuan siswa kelas tujuh (VIII) SMPN 1 Kesamben terhadap pembelajaran PJOK materi atletik lari estafet termasuk dalam kategori tinggi dengan persentase rata - rata sebesar $69,1 \%$.
\end{abstract}

\begin{abstract}
Aim in this study was to find out whether the WhatsApp combination online learning model had an influence on the learning outcomes of the seventh grade of SMPN 1 Kesamben (VIII) students during the covid 19 pandemic. The type of research used in this study was descriptive quantitative. Descriptive research method is research conducted to describe certain symptoms, phenomena or events (Sugiyono, 2007:11). The analysis technique in this study uses descriptive quantitative analysis techniques with percentage scores. The results showed that the attitude indicator obtained $72.2 \%$, the running technique indicator $61 \%$, the knowledge indicator $74.3 \%$. It can be concluded that the knowledge of seventh grade students (VIII) of SMPN 1 Kesamben towards learning PJOK for relay athletics is included in the high category with an average percentage of $69.1 \%$.
\end{abstract}




\section{Journal STAND: Sports and Development}

http://jurnal.unipasby.ac.id/index.php/stand/about/submissions jurnal.stand@unipasby.ac.id

\section{PENDAHULUAN}

Pendidikan memegang peranan penting dalam mempersiapkan sumber daya manusia yang berkualitas dan mampu berkompetensi dalam perkembangan ilmu pengetahuan dan teknologi, sehingga pendidikan harus dilaksanakan dengan sebaik - baiknya untuk memperoleh hasil maksimal. Pendidikan hendaknya dikelola, baik secara kualitas maupun kuantitas. Hal tersebut dapat dicapai dengan terlaksananya pendidikan yang tepat waktu dan tepat guna untuk mencapai tujuan pendidikan.

Pendidikan bukan hanya sebagai sarana untuk menyiapkan individu bagi kehidupannya di masa depan, tetapi juga untuk kehidupan anak masa sekarang yang sedang mengalami perkembangan menuju ke tingkat pendewasaan. Dalam hal ini pendidikan memegang peranan penting bagi perkembangan anak agar mampu berkembang secara optimal, karena pendidikan anak merupakan sumber pedoman atau fondasi di masa mendatang. Hal tersebut diperkuat atas pendapat Rohman (2011 : 25) fondasi pendidikan adalah sesuatu yang memberikan dasar atau landasan terhadap penyelenggaraan sistem pendidikan yang dilakukan di masyarakat. Pendidikan yang diterapkan dengan benar akan mengembangkan anak yang baik, sebaliknya apabila pendidikan diterapkan tidak sesuai dengan perkembangan anak, maka anak akan mengalami kesulitan dalam belajar.
Pendidikan jasmani mempunyai peranan penting bagi dunia pendidikan dan peserta didik, karena Pendidikan jasmani adalah suatu proses pembelajaran melalui aktivitas jasmani yang di desain untuk meningkatkan kebugaran jasmani, mengembangkan keterampilan motorik, pengetahuan dan perilaku hidup sehat dan aktif, sikap sportif, dan kecerdasan emosi, menurut (Samsudin, 2008 : 2). Definisi ini mengandung makna bahwa, pendidikan jasmani merupakan suatu mata pelajaran yang kompleks, dengan memanfaatkan aktivitas jasmani sebagai sarana untuk mencapai tujuan dari pendidikan.

Pembelajaran merupakan proses interaksi langsung peserta didik dengan pendidik dan sumber belajar pada suatu lingkungan belajar. Namun Dalam kondisi saat ini Indonesia merupakan salah satu dari 100 negara yang terdampak pendemi virus corona atau covid 19. Situasi Pandemi COVID-19 akan berdampak dari berbagai sektor kehidupan seperti ekonomi, sosial, termasuk juga pendidikan. Organisasi Pendidikan, Keilmuan, dan Kebudayaan Perserikatan Bangsa-Bangsa menyatakan bahwa, wabah virus corona telah berdampak terhadap sektor pendidikan. Hampir 300 juta siswa terganggu kegiatan sekolahnya di seluruh dunia dan terancam berdampak pada hak-hak pendidikan mereka di masa depan. Di Indonesia sendiri, dunia pendidikan juga ikut merasakan dampaknya. Dampak yang 


\section{Journal STAND: Sports and Development}

http://jurnal.unipasby.ac.id/index.php/stand/about/submissions jurnal.stand@unipasby.ac.id

paling dirasakan adalah peserta didik di instansi penyelenggara pelayanan pendidikan, seperti sekolah di semua tingkatan, lembaga pendidikan non formal hingga perguruan tinggi tidak bisa melaksanakan proses kegiatan belajar mengajar secara tatap muka dan alternatif kegaiatan belajar disemua sekolahan dilaksanakan secara daring memanfaatkan teknologi yang semakin modern. Hal ini menyebabkan pendidikan di Indonesia terganggu untuk saat ini. Salah satu upaya yang bisa dilakukan untuk memajukan pendidikan di Indonesia ditengah wabah pandemi covid 19 adalah dengan melakukan inovasi pembelajaran melalui Pemanfaatkan teknologi, informasi, dan komunikasi. Hal ini didukung dengan perkembangan teknologi yang semakin cepat membuat internet terus berkembang. Inetrnet sebagai media jarak jauh dan media pembelajaran (learning).

Pembelajaran daring Secara umum adalah suatu pembelajaran yang dilakukan secara elektronik dengan mengunakan media berbasis komputer, hand phone serta sebuah jarinngan elektronik.pembelajaran online dikenal juga dengan istilah pembelajaran elektronik, e-Learning, on-line learning, internet-enabled learning. Penggunaan teknologi dan informasi saat-saat ini terus mengalami perkembangan tanpa perkecualian teknologi dan informasi dalam dunia pendidikan. Menurut (Darin E.Hartley,2001) mengemukakan bahwa pengertian E-learning adalah suatu jenis belajar mengajar yang memungkinkan tersampaikanya bahan ajar ke siswa dengan mengunakan media internet. Proses pembelajaran menggunakan Elearning sangat berbeda dengan proses pembelajaran yang terjadi di dalam kelas. Jika proses pembelajaran menggunakan E-learning peserta didik dan guru tidak dituntut dalam satu ruang dan satu waktu, sedangkan proses pembelajaran di dalam kelas peserta didik dan guru dituntut untuk satu ruang dan satu waktu, kedudukan peserta didik sebagai objek yang harus duduk, bergerak dengan batasan, dan harus memperhatikan guru saat menerangkan.

Sebelum melakukan penelitian ini penulis mengetahui pembelajaran saat ini melaui pembelajaran daring berbasis WHATSAPP selama kurang lebih 1 tahun di SMPN 1 KESAMBEN JOMBANG, dari sini penulis dapat mengetahui bahwa guru pendidikan jasmani di sekolah tersebut pada saat ini mengajar secara daring tanpa adanya pertemuan di sekolah dimasa pandemi virus COVID 19, setelah itu seluruh siswa melakukan aktifitasnya secara bebas tanpa adanya pengawasan dari guru. Disamping itu juga dipengaruhi karena adanya virus covid 19 yang sedang melanda di Indonesia maka proses pembelajaran dilakakukan dengan daring menggunakan whatsapp.

Melihat uraian di atas peneliti mencoba untuk mengetahui tentang peranan guru pada saat mengahdapi kondisi pembelajaraan daring saat ini. Berdasarkan latar belakang 
http://jurnal.unipasby.ac.id/index.php/stand/about/submissions jurnal.stand@unipasby.ac.id

diatas maka penulis menyusun proposal dengan judul : "Survei Model Pembelajaran Daring Kombinasi Whatsapp Pada Materi Lari Estafet kelas VIII SMPN 1 KESAMBEN".

\section{METODE PENELITIAN}

Jenis penelitian yang digunakan dalam penelitian ini adalah desakriptif kuantitatif. Metode penelitian deskriptif adalah penelitian yang dilakukan untuk menggambarkan gejala, fenomena atau peristiwa tertentu (Sugiyono, 2007:11). Jadi yang dimaksud penelitian kuantitatif adalah penelitian yang dilakukan untuk mengetahui nilai variabel mandiri, tanpa membuat perbandingan dari data yang berbentuk kualitatif yang diangkakan. Objek dalam penelitian ini adalah SMPN 1 KESAMBEN. Dalam penelitian ini peneliti menggunakan angket sebagai instrumen penelitian.

Sampel dalam penelitian adalah siswa siswi SMPN 1 Kesamben yang terdiri dari kelas VIII - A yang terdiri dari 25 siswa , 25 siswa kelas VIII - B. Maka jumlah keseluruhan sebanyak 50 siswa yang menjadi responden.

\section{HASIL DAN PEMBAHASAN}

Hasil penelitian akan dikaitkan dengan tujuan penelitian sebagaimana yang telah dikaitkan dengan pembahasan selanjutnya. Maka akan diuraikan oleh peneliti tentang pembelajaran lari estafet menggunakan daring yang dapat diuraikan dekripsi data dari pengujian tersebut.
Penelitian ini digunakan untuk mengetahui besarnya pengaruh pembelajaran lari estafet menggunakan daring pada siswa siswi kelas VIII A\&B di SMPN 1 Kesamben tahun ajaran 2020/2021. Hasil penelitian tersebut dideskripsikan sebagai berikut.

\section{Analisis angket pembelajaran lari estafet}

Berdasarkan hasil penelitian tentang pembelajaran lari estafet menggunakan daring pada siswa kelas VII SMPN 1 Kesamben pembelajaran PJOK materi atletik lari estafet tahun ajaran 2020/2021. Memperoleh data dari pembelajaran lari estafet menggunakan daring pada siswa kelas VIII A\&B dari hasil angket/kuisioner yang terdiri dari 25 item pernyataan dengan menggunakan skala likert yang terdiri dari lima alternatif jawaban yaitu : (STM) Sangat Tidak Mengerti, (TM) Tidak Mengerti, (CM) Cukup Mengerti, (M) Mengerti, (SM) Sangat Mengerti. Responden diminta memilih dari lima alternatif jawaban yang disediakan pada setiap peryataan melalu google form dengan memberikan tanda (o) pada kolom yang sudah disediakan. Skor maksimal yang diberikan dari alternatif jawaban yaitu 5 dan minimal yaitu 1 . Berdasarkan 25 butir pernyataan yang ada dengan jumlah responden sebanyak 50 siswa. Menunjukkan bahwa dari skor tertinggi yang mungkin dicapai sebesar $5 \times 25=125$ dan skor terendah $1 \times 25=25$ data.

Hasil penelitian kali ini menyajikan data dari penyebaran angket kepada 50 siswa SMP 


\section{Journal STAND: Sports and Development}

http://jurnal.unipasby.ac.id/index.php/stand/about/submissions jurnal.stand@unipasby.ac.id

Negeri 1 Kesamben kelas tujuh (VIII) yang dilakukan secara acak. Data tersebut berupa skor yang nantinya akan di persentasekan pada setiap indikator maupun setiap pernyataan. Adapun data yang akan peneliti sajikan pada bab ini meliputi:

1. Perhitungan setiap pernyataan pada angket.

2. Kesimpulan dari pernyataan dalam angket.

3. Hasil perhitungan per indikator.

4. Total perhitungan indicator

Berdasarkan 25 butir pernyataan yang merupakan pernyataan dengan kategori sangat tinggi yakni pernyataan terdapat 5 butir pernyataan. Sedangkan pernyataan dengan kategori tinggi terdapat 16 butir pernyataan. Kemudian untuk pernyataan dengan kategori cukup terdapat 3 butir.

Tabel 1. Hasil perhitungan per indikator

\begin{tabular}{|l|l|l|l|}
\hline No. & Indikator & Hasil & Kategori \\
\hline 1. & Sikap & $\begin{array}{l}72,2 \\
\%\end{array}$ & Tinggi \\
\hline 2. & Teknik Lari & $61 \%$ & Tinggi \\
\hline 3. & Pengetahuan & $74,3 \%$ & Tinggi \\
\hline
\end{tabular}

Berdasarkan gambar tabel di atas dapat diketahui hasil perhitungan masing-masing indikator yakni sebagai berikut:

1. Indikator sikap pada perhitungan tabel diatas mendapati hasil perhitungan persentase sebesar $72,2 \%$, hasil tersebut menunjukkan bahwa indikator sikap masuk dalam kategori tinggi.

2. Pada tabel diatas indikator teknik lari mendapat hasil perhitungan persentase sebesar $61 \%$, hasil tersebut masuk dalam kategori tinggi.

3. Indikator pengetahuan memperoleh hasil perhitungan persentase sebesar $74,3 \%$, ini menunjukkan bahwa indikator pengetahuan termasuk kategori tinggi.

Berdasarkan perhitungan diatas dapat diketahui bahwa rata-rata total atau yang diperoleh dari penjumlahan semua indikator kemudian dibagi tiga (3) sesuai banyaknya indikator pada angket pembelajaran materi atletik lari jarak pendek 100meter sebesar $69,1 \%$ hal ini termasuk dalam kategori tinggi.

Hasil yang didapat pada penelitian kali ini dari 50 responden berdasarkan perhitungan per item pernyataan dan per indikator dari hasil penelitian yang diambil melalui google form dan dikerjakan oleh responden melalui handphone atau komputernya masing-masing. Penelitian ini menggunakan angket untuk mengambil data dari responden guna menjawab rumusan masalah. Penelitian kali ini dilaksanakan di SMP Negeri 1 Kesamben. Penelitian yang berjudul "Survei Model Pembelajaran Daring Kombinasi Whatsapp Pada Materi Lari Estafet kelas VIII SMPN 1 KESAMBEN" menggunakan angket untuk mengambil data yang terdiri dari 25 pernyataan yang dibedakan berdasarkan indikator yang telah 


\section{Journal STAND: Sports and Development}

http://jurnal.unipasby.ac.id/index.php/stand/about/submissions jurnal.stand@unipasby.ac.id

ditetapkan, yaitu meliputi indikator sikap, indikator teknik lari, indikator pengetahuan. Angket tersebut mengandung lima alternatif jawaban dan menggunakan skala likert untuk mengukur minat. Setelah mendapatkan jawaban atau data dari responden yang berjumlah 50 siswa, data kemudian dianalisis menggunakan rumus pada microsoft excel untuk mengetahui persentase yang diperoleh sehingga dapat diketahui tingkatan pemahaman pembelajaran materi atletik lari jarak pendek 100 meter.

Masuk pada indikator yang ada didalam angket penelitian kali ini, ketiga indikator memperoleh persentase dalam kategori tinggi akan tetapi perolehan persentase tertinggi didapat indikator pengetahuan dengan $74,3 \%$ dan diikuti indikator sikap dengan persentase $72,2 \%$, dan yang terakhir indikator teknik lari dengan persentase $61 \%$. Melihat hasil yang didapat menunjukkan pengetahuan siswa kelas VIII (tujuh) SMPN 1 Kesamben terhadap materi pembelajaran atletik lari 100meter masuk dalam kategori yang tinggi. Pada indikator pengetahuan terdapat berbagai subindikator yang berisikan pengertian, peraturan, diskualifikasi, sarana dan prasarana serta sejarah lari. Persentase yang didapat pada indikator pengetahuan dapat dikatakan bahwasannya siswa kelas tujuh SMPN 1 Kesamben memiliki pemahaman yang tinggi pada pengetahuan materi atletik lari estafet.

Indikator berikutnya yakni indikator sikap, pada indikator sikap terdapat subindikator antara lain awalan/start, lari, finish. Indikator sikap memuat tingkat pemahaman akan sikap yang dilakukan oleh pelari estafet pada saat sebelum dan sesudah berlari. Indikator sikap memperoleh persentase sebesar $72,2 \%$ hal ini menunjukkan indikator sikap masuk dalam kategori tinggi, hasil yang didapat menunjukkan bahwasannya siswa kelas tujuh SMPN 1 Kesamben memahami bagaimana sikap pelari estafet dalam melakukan lari maupun sebelum dan sesudah melakukan lari.

Indikator teknik lari merupakan sebuah indikator yang menyajikan sebuah pemahaman tentang teknik yang digunakan pada waktu seorang pelari melkukan lari, terdapat dua subindikator yaitu fase topang dan fase layang. Indikator teknik lari masuk dalam kategori tinggi dengan mendapati persentase sebesar $61 \%$ walau begitu indikator teknik lari memiliki persentase terkecil dibanding dua indikator sebelumnya yakni indikator sikap dan indikator pengetahuan. Hasil yang didapat oleh indikator teknik lari menunjukkan bahwasannya siswa SMPN 1 Kesamben memahami teknik dalam berlari.

Berdasarkan paparan dan hasil perhitungan oleh peneliti serta didukung oleh peneliti terdahulu menunjukan bahwa adanya keefektifan pembelajaran lari estafet menggunakan daring melalui aplikasi whatsapp (googel form) pada hasil pemahaman siswa tentang materi 


Journal STAND: Sports and Development
http://jurnal.unipasby.ac.id/index.php/stand/about/submissions
jurnal.stand@unipasby.ac.id

pembelajaran Pendidikan Jasmani Olahraga dan Kesehatan pada lari jarak pendek.

\section{KESIMPULAN}

Berdasarkan hasil dari penelitian dan pembahasan yang telah diuraikan pada bab sebelumnya, menunjukkan bahwa indikator sikap memperoleh prosentase sebesar $72,2 \%$, kemudian pada indikator teknik lari memperoleh $61 \%$, indikator pengetahuan memperoleh nilai sebesar 74,3\%. Dari ke tiga indikator tersebut dapat disimpulkan bahwa pengetahuan siswa kelas tujuh (VIII) SMPN 1 Kesamben terhadap pembelajaran atletik lari estafet termasuk dalam kategori tinggi dengan rata rata jumlah persentase sebesar $69,1 \%$.

Berdasarkan hasil diatas dapat disimpulkan bahwa pembelajaran lari estafet menggunakan daring memiliki pengaruh yang efektif dalam proses pemahaman siswa tentang pembelajaran lari estafet di SMPN 1 Kesamben.

\section{REFERENSI}

Arikunto, Suharsimi. (2006). Prosedur Penelitian Suatu Pendekatan Praktik. Jakarta, Indonesia: PT Rineka Cipta

A. Widya. Muchammad Jumidar. 2004. Gerak-Gerak Dasar Atletik dalam Bermain. Jakarta: PT. Raja Grafindo
Persada

Darin E. Hartley, Selling E-Learning, America Society For Traning and Development. 2001

Rohman, Arif. 2011. Memahami Pendidikan dan Ilmu Pendidikan. Yogyakarta: CV Aswaja Pressindo

Samsudin. 2008. Pembelajaran Pendidikan Jasmani Olahraga dan Kesehatan SMA / MA. Jakarta: Litera.

Saputra Yudha M. (2001). Pembelajaran Atletik di Sekolah Menengah Pertama. Jakarta, Indonesia: Direktoral Jendral Olahraga

Sidik, Zafar Dikdik. (2010). Mengajar dan Melatih Atletik. Bandung, Indonesia: Remaja Rosdakarya

Sugiyono. (2007). Metode Penelitian Pendidikan Pendekatan Kuantitatif, Kualitatif dan $R \& D$. Bandung, Indonesia: Alfabeta 